\title{
Knowledge, Attitude, Practice, Risk Perception and Challenges Towards COVID-19 in East Gojjam Zone, North West Ethiopia, Cross Sectional Study
}

Bekele Tesfaye ( $\square$ bekeletesfaye76@gmail.com )

Debre Markos University https://orcid.org/0000-0001-6972-7441

Muluneh Alene

Debre Markos University

Wodaje Gietaneh

Debre Markos University

Yonnas Lamore

Debre Markos University

Mulu Mola

Debre Markos University

Moges Wube

Debre Markos University

Nackachew Mekonen

Debre Markos University

Moges Agazhe

Debre Markos University

Yilkal Tafere

Debre Markos University

Getenet Gedif

Debre Markos University

Atsede Alle

Debre Markos University

Bekalu kassie

Debre Markos University

Genet Degu

Debre Markos University

Alemu Gebrie

Debre Markos University

Research 
Keywords: Knowledge, Attitude, Practice, Risk Perception, COVID-19, Ethiopia

Posted Date: April 5th, 2021

DOI: https://doi.org/10.21203/rs.3.rs-376761/v1

License: (c) (1) This work is licensed under a Creative Commons Attribution 4.0 International License. Read Full License 


\section{Abstract}

Background: Understanding how people perceive the risk of the coronavirus disease outbreak and its impact on undertaking protective behavior can guide the public health policymakers in taking the required measures to limit the magnitude of this outbreak.

Objective: This study aimed to assess the knowledge, risk perceptions, and uptake of preventive measures towards COVID-19 in East Gojjam zone.

Methods: A mixed method study in order to obtain in-depth behavioral insights related to COVID-19 pandemic prevention measures was conducted in the four randomly selected Woredas of East Gojjam Zone. A flexible data collection tool adapted from World Health Organization (WHO) for quantitative component, and in-depth interview for qualitative component was used. Binary logistic regression analysis was conducted to analyze quantitative data, and while content analysis was used for qualitative component.

Results: In this study, a total of 661 study participants were included. Nearly two-third (65.5\%) of respondents is residing in the rural area. Only $59.6 \%$ of respondents had better understanding of COVID19 pandemic. Similarly, less-than one-fifth (14.5\%) of individuals had favorable attitude towards COVID19. This study showed that only one-fifth $(20.9 \%)$ of study participants had good preventive practices. Respondent's residing in urban area (AOR: $0.1,95 \% \mathrm{Cl}: 0.08,0.2$ ), who had age between 35 and 45 (AOR: $0.4,95 \% \mathrm{Cl}: 0.2,0.8$ ), and having secondary and above education level (AOR: $0.2,95 \% \mathrm{Cl}: 0.1,0.5$ ) had better awareness towards COVID-19 as compared to its counterparts. Similarly, study participants who had better knowledge ((AOR: 3.0, 95\%Cl: 1.7, 5.5), and residing in urban area had favorable attitude towards COVID-19. Furthermore, respondents with confirmed comorbidity had good preventive practice towards COVID-19.

Conclusion and recommendation: In this study, the level of knowledge, attitude and preventive practice towards COVID-19 is low. Residing in rural area, not having formal education, being housewife were factors significantly associated with the poor level of knowledge, attitude, and preventive practice towards COVID-19. Address peoples living in rural area through health professional to create public awareness towards COVID-19 is recommended.

\section{Background}

The coronavirus belongs to a family of viruses that may cause various symptoms such as pneumonia, fever, breathing difficulty, and lung infection (1). These viruses are common in animals worldwide, but very few cases have been known to affect humans. Coronavirus disease 2019 (COVID-19) is a new, rapidly emerging zoonotic infectious disease (2). The first COVID-19 case was reported from on 31 December 2019 in Wuhan, a city in the Chinese province of Hubei (3). The novel coronavirus SARS-CoV-2 disease has been named "COVID-19" by the World Health Organization (WHO) on January 30, 2020. COVID-19 is a rapidly spreading infectious disease, which has now established a global pandemic. 
The novel corona virus is genetically similar to other coronaviruses that caused Severe Acute Respiratory Syndrome (SARS) and the Middle East Respiratory Syndrome (MERS). SARS-CoV-2 appears to have greater transmissibility and lower pathogenicity than the aforementioned viruses. Preliminary estimates of the basic reproduction number of SARS-CoV-2, as a metric for transmissibility, range from 2.8 to 5.5 , in the absence of intense quarantine and social distancing measures (4).

To date, no effective pharmacological interventions or vaccines are available to treat or prevent COVID19. For this reason, non-pharmacological public health measures such as isolation, social distancing, and quarantine are the only effective ways to respond to the outbreak. Isolation refers to the separation of symptomatic patients whereas quarantine is the restriction of asymptomatic healthy people who have had contact with confirmed or suspected cases. Quarantine can be implemented on a voluntary basis or can be legally enforced by authorities and may be applied at an individual, group, or community level (5).

At this time, WHO and the US Center for Disease Control and Prevention (CDC) recommend 14 days of quarantine for individuals who were in close contact with a confirmed case, based on the estimated incubation period of SARS-CoV-2 $(6,7)$. According to early estimates by China's National Health Commission, about $80 \%$ of those who died were over the age of 60 and $75 \%$ of them had pre-existing health conditions such as cardiovascular diseases and diabetes (8). While there is still much to learn about COVID-19, people can take action to prevent the disease through simple, day-to-day measures. These include the following precautions: Regularly and thoroughly washing hands with soap and water and use alcohol-based hand sanitizer. Maintain a physical distance of at least one meter, particularly if a person is coughing. Persons with persistent cough or sneezing should stay home or keep a social distance, and not mix in crowds. Make sure you are coughing into a tissue or a bent elbow, and make sure to safely dispose of the used tissue afterwards. Stay home if you feel unwell with symptoms like fever, cough and difficulty in breathing. Understanding how people perceive the risk of the coronavirus disease outbreak and its impact on undertaking protective behavior can guide the public health policymakers in taking the required measures to limit the magnitude of this outbreak. To date, there is no evidence that shows the level community awareness and uptake of preventive measures in Ethiopia.

\section{Objective}

The general objective of this study was to assess the Knowledge, Attitude, practice, risk perceptions and challenges towards COVID-19 in East Gojjam Zone, North West Ethiopia, 2020.

\section{Methods}

\section{Study area}

The study was conducted in east Gojjam Zone. This zone is bordered on the south by the Oromia Region, on the west by West Gojjam, on the north by south Gondar, and on the east by Debub Wollo and the bend of the Abay river defines the Zone's northern, eastern and southern boundaries. Based on the 2007 census 
conducted by the central statistical agency of Ethiopia, this Zone has a total population of 2,153,937. In the administrative Zone there are 423 and 102 health posts and health centers respectively. In addition, in this Zone there are nine primary hospitals and only one referral hospital (26).

\section{Study design and population}

A mixed method study in order to obtain an in-depth behavioral insight related to COVID-19 pandemic prevention measures was conducted in the four randomly selected Woredas of East Gojjam Zone. All residents in East Gojjam Zone are the source population, while the selected residents in the selected woredas and town at the time of data collection period were the study population of this study.

\section{Study participants and sampling procedure}

This study was undertaken in four randomly selected Woredas of east Gojjam zone namely: Awabel, Enemay, Debre Elias and Motta. The sample size is determined using sample size determination formula for single population proportion formula. Accordingly, the minimum adequate sample size is calculated with the assumption of $26.9 \%$ of individuals perceived their risk of getting COVID-19 infection (taken from the previous study), significant level at $a=0.05$, margin of error $=5 \%, 10 \%$ non-response rate and multiplying by two (for design effect). Thus, a minimum sample size of 1330 will be needed after considering design effect. Next, the calculated sample size will proportionally allocate for each woredas.

\section{Operational definition}

Knowledge: In the context of this study knowledge towards COVID-19 will defined as understanding symptoms, actual knowledge about effective preventive measures to avoid infection, and other related information related to novel coronavirus. A respondent is considered having good knowledge if he/she answered two-third and above knowledge related questions, while poor knowledge is considered if the respondent answered below two-third of knowledge related questions.

Attitude: Understanding and interpreting the susceptibility and severity of COVID-19 disease. Favorable attitude: if the respondent answered above the mean of attitude related questions. Unfavorable attitude: if the respondent answered below the mean of attitude related questions practicing of preventive measures: The utilization of recommended preventive measures to avoid an infection with the novel corona virus. An individual is considered practicing preventive measures to COVID-19, if he /she utilize all recommended preventive measures (Frequent hand washing or use of sanitizer, maintaining physical distance).

\section{Variables and measurements}


The following variables were measured in this study: Demographics (Age, Gender, marital status, education, religious, and occupation.....), Knowledge about the novel coronavirus, Attitude regarding the COVID-19, Uptake of preventive measures to avoid infection with COVID-19 and Individual feeling of preparedness to avoid an infection with the coronavirus

\section{Data collection tool and analysis}

A flexible data collection tool adapted from WHO was used. The data collection tool was pilot-tested in one non-study woredas. To assure the data quality, high emphasis was given in designing data collection instrument. Regular meetings were held between the data collectors, supervisors and the principal investigators together in which problematic issues was discussed and addressed. The collected data was reviewed and checked for completeness before leaving the data collection sites. Binary logistic regression analysis was conducted analyze quantitative data. For qualitative component content analysis was applied.

\section{Results}

\section{Socio-demographic characteristics of respondents}

In the quantitative component of this study, a total of 661 study participants were included. About $37.5 \%$ of study participants were males. Nearly two-third (433(65.5\%)) of respondents are residing in the rural area. Of the total study participants, majority (534 (80.8\%)) were married. About half $(51.4 \%)$ of individuals are without formal education, and only $13.3 \%$ of respondents had secondary and above education level. 
Table 1

Descriptive results of socio-demographic and economic characteristics of respondents in east Gojjam Zone, 2020

\begin{tabular}{|c|c|c|c|}
\hline Variables & Total (\%) & Variables & Total (\%) \\
\hline \multicolumn{2}{|l|}{ Gender } & \multicolumn{2}{|l|}{ Education } \\
\hline \multirow{3}{*}{$\begin{array}{l}\text { Male } \\
\text { female }\end{array}$} & \multirow{2}{*}{$\begin{array}{l}248 \\
(37.5)\end{array}$} & No formal education & $340(51.4)$ \\
\hline & & Primary school & $233(35.2)$ \\
\hline & $\begin{array}{l}413 \\
(62.5)\end{array}$ & $\begin{array}{l}\text { Secondary and } \\
\text { above }\end{array}$ & $88(13.3)$ \\
\hline \multicolumn{2}{|l|}{ Residence } & \multicolumn{2}{|l|}{ Occupation } \\
\hline \multirow{4}{*}{$\begin{array}{l}\text { Rural } \\
\text { Urban }\end{array}$} & $\begin{array}{l}433 \\
(65.5)\end{array}$ & $\begin{array}{l}\text { Government } \\
\text { employee }\end{array}$ & $84(12.7)$ \\
\hline & \multirow{3}{*}{$\begin{array}{l}228 \\
(34.5)\end{array}$} & \multirow{3}{*}{$\begin{array}{l}\text { Farmer } \\
\text { Merchant } \\
\text { House wife }\end{array}$} & $396(59.9)$ \\
\hline & & & $65(9.8)$ \\
\hline & & & $116(17.5)$ \\
\hline \multirow{2}{*}{$\begin{array}{l}\text { Marital } \\
\text { status }\end{array}$} & \multirow{3}{*}{$\begin{array}{l}52(7.9) \\
534 \\
(80.8)\end{array}$} & \multicolumn{2}{|l|}{ Family size } \\
\hline & & $\leq 3$ & $292(44.2)$ \\
\hline $\begin{array}{l}\text { Unmarried } \\
\text { Married }\end{array}$ & & \multirow[t]{3}{*}{$\geq 4$} & \multirow[t]{3}{*}{$369(55.8)$} \\
\hline Divorced & $50(7.6)$ & & \\
\hline Widowed & $25(3.8)$ & & \\
\hline \multicolumn{2}{|l|}{ Age } & \multicolumn{2}{|l|}{ Comorbidity } \\
\hline$\leq 25$ & 75 (11.3) & Yes & $139(21.0)$ \\
\hline $26-35$ & \multirow{2}{*}{$\begin{array}{l}269 \\
(40.7)\end{array}$} & No & $460(69.6)$ \\
\hline \multirow{2}{*}{$\begin{array}{l}35-45 \\
\geq 46\end{array}$} & & \multirow[t]{2}{*}{ Unknown } & \multirow[t]{2}{*}{$629.4)$} \\
\hline & 119 (18) & & \\
\hline
\end{tabular}

\section{Level of knowledge, attitude and preventive practice towards COVID-19 pandemic}

The result of this study revealed that only $59.6 \%(95 \% \mathrm{Cl}: 56,63.4)$ of respondents had better understanding of COVID-19 pandemic. These include recognizing ways of transmission, preventive measures and symptoms. Similarly, only $14.5 \%(95 \% \mathrm{Cl}: 11.6,17.1)$ of individuals had favorable attitude towards COVID-19. More specifically, about $30 \%$ of individuals believed that COVID-19 comes for sinners. In addition, nearly $16.3 \%$ of respondents think that the government used COVID-19 for political issue. 
Moreover, this study showed that only one-fifth (20.9\%) of study participants had good preventive practices. About $31 \%$ of individuals are wearing mask in crowded area. Of the total interviewed study participants, about $41 \%$ of them maintain physical distancing.

\section{Factors associated with the level of knowledge towards COVID-19 pandemic}

Multivariable binary logistic regression analysis was conducted to identify the determinant factors associated with the level knowledge (Table 2). Accordingly; residence, age of respondent, educational level, and occupation were factors significantly associated with the level of knowledge towards COVID19. Respondent's residing in urban area had better knowledge (AOR: $0.1,95 \% \mathrm{Cl}: 0.08,0.2)$ than individuals living in rural area. The level of knowledge among study participants who had age between 35 and 45 are more-likely (AOR: $0.4,95 \% \mathrm{Cl}: 0.2,0.8$ ) than respondents who had age less-than 25 years.

The odds of knowledge towards COVID-19 is more-likely (AOR: $0.2,95 \% \mathrm{Cl}: 0.1,0.5$ ) among respondents who had secondary and above educational level than individuals without formal education. Furthermore, housewife respondents had low level of knowledge (AOR: $5.1,95 \% \mathrm{Cl}: 1.7,15.5)$ than government employee. 
Table 2

Univariable and multivariable binary logistic regression analysis on factors associated with the level knowledge towards COVID-19 in east Gojjam Zone, 2020.

\begin{tabular}{|c|c|c|c|c|}
\hline \multirow[t]{2}{*}{ Variables } & \multicolumn{2}{|c|}{ Level of knowledge } & \multirow[t]{2}{*}{$\operatorname{COR}(95 \% \mathrm{Cl})$} & \multirow[t]{2}{*}{ AOR(95\%Cl) } \\
\hline & Poor knowledge & Good knowledge & & \\
\hline \multicolumn{5}{|l|}{ Gender } \\
\hline Male & 109 & 139 & Ref. & Ref. \\
\hline female & 158 & 255 & $1.2(0.9,1.7)$ & $0.7(0.5,1.0)$ \\
\hline \multicolumn{5}{|l|}{ Residence } \\
\hline Rural & 237 & 196 & Ref. & Ref. \\
\hline Urban & 30 & 198 & $0.1(0.01,0.2)$ & $0.1(0.08,0.2)$ \\
\hline \multicolumn{5}{|l|}{ Marital status } \\
\hline Unmarried & 21 & 31 & Ref. & Ref. \\
\hline Married & 213 & 321 & $0.9(0.5,1.8)$ & $0.9(0.5,1.7)$ \\
\hline Divorced & 23 & 27 & $1.3(0.6,2.8)$ & $1.1(0.4,2.5)$ \\
\hline Widowed & 10 & 15 & $0.9(0.4,2.6)$ & $0.1(0.08,0.2)$ \\
\hline \multicolumn{5}{|l|}{ Age } \\
\hline$\leq 25$ & 41 & 34 & Ref. & Ref. \\
\hline $26-35$ & 95 & 174 & $0.5(0.3,0.8)$ & $0.3(0.2,0.6)$ \\
\hline $35-45$ & 91 & 107 & $0.7(0.4,1.2)$ & $0.4(0.2,0.8)$ \\
\hline$\geq 46$ & 40 & 79 & $0.4(0.2,0.8)$ & $0.2(0.1,0.4)$ \\
\hline \multicolumn{5}{|l|}{ Education } \\
\hline No education & 188 & 152 & Ref. & Ref. \\
\hline Primary school & 72 & 161 & $0.4(0.3,0.5)$ & $0.4(0.3,0.6)$ \\
\hline Secondary+ & 7 & 81 & $0.1(0.03,0.2)$ & $0.2(0.1,0.5)$ \\
\hline \multicolumn{5}{|l|}{ Occupation } \\
\hline Gov.employee & 5 & 79 & Ref. & Ref. \\
\hline Farmer & 208 & 188 & $17.5(6.9,44.1)$ & $8.8(2.9,24.9)$ \\
\hline Merchant & 14 & 51 & $4.3(1.5,12.8)$ & $2.9(0.9,9.4)$ \\
\hline House wife & 40 & 76 & $8.3(3.1,22.2)$ & $5.1(1.7,15.5)$ \\
\hline
\end{tabular}




\begin{tabular}{|lllll|}
\hline Variables & \multicolumn{2}{l}{ Level of knowledge } & COR(95\% Cl) & AOR(95\%Cl) \\
\cline { 2 - 3 } & Poor knowledge & Good knowledge & & \\
\cline { 1 - 2 } Family size & & & & \\
$\leq 3$ & 105 & 187 & Ref. & Ref. \\
$\geq 4$ & 162 & 207 & $1.4(1.0,1.9)$ & $1.3(0.9,1.9)$ \\
Comorbidity & & & & \\
Yes & 60 & 79 & Ref. & Ref. \\
No & 182 & 278 & $0.9(0.6,1.3)$ & $0.8(0.5,1.2)$ \\
Unknown & 25 & 37 & $0.8(0.5,1.6)$ & $0.9(0.4,1.7)$ \\
\hline
\end{tabular}

\section{Factors associated with the level of attitude towards COVID-19 pandemic}

In the multivariable logistic regression analysis, residence, level of knowledge, occupation, and having confirmed comorbidity were factors associated the level of attitude towards COVID-19 (Table 3).

Respondents residing in urban area had favorable attitude (AOR: $0.5,95 \% \mathrm{Cl}: 0.3,0.8)$ ) towards COVID-19 than study participants living in rural area. The result of this study revealed that study participants who had better awareness are more-likely (AOR: $3.0,95 \% \mathrm{Cl}$ : 1.7, 5.5) to have favorable awareness. 
Table 3

Univariable and multivariable binary logistic regression analysis on factors associated with the level Attitude towards COVID-19 in east Gojjam Zone, 2020

\begin{tabular}{|c|c|c|c|c|}
\hline \multirow[t]{2}{*}{ Variables } & \multicolumn{2}{|l|}{ Level of Attitude } & \multirow[t]{2}{*}{ COR(95\%Cl) } & \multirow[t]{2}{*}{$\mathrm{AOR}(95 \% \mathrm{Cl})$} \\
\hline & Unfavorable attitude & Favorable attitude & & \\
\hline \multicolumn{5}{|l|}{ Gender } \\
\hline Male & 222 & 26 & Ref. & Ref. \\
\hline female & 343 & 70 & $0.6(0.4,0.9)$ & $0.6(0.4,1.01)$ \\
\hline \multicolumn{5}{|l|}{ Residence } \\
\hline Rural & 384 & 49 & Ref. & Ref. \\
\hline Urban & 181 & 47 & $0.5(0.3,0.8)$ & $0.5(0.3,0.8)$ \\
\hline \multicolumn{5}{|l|}{ Marital status } \\
\hline Unmarried & 42 & 10 & Ref. & Ref. \\
\hline Married & 459 & 75 & $1.4(0.7,3.0)$ & $1.4(0.7,3.0)$ \\
\hline Divorced & 41 & 9 & $1.01(0.4,2.9)$ & $1.0(0.4,2.8)$ \\
\hline Widowed & 23 & 2 & $2.7(0.6,13.6)$ & $0.5(0.3,0.8)$ \\
\hline \multicolumn{5}{|l|}{ Age } \\
\hline$\leq 25$ & 57 & 18 & Ref. & Ref. \\
\hline $26-35$ & 219 & 50 & $1.4(0.8,2.6)$ & $1.5(0.7,2.9)$ \\
\hline $35-45$ & 181 & 17 & $3.4(1.6,6.9)$ & $3.0(1.3,7.2)$ \\
\hline$\geq 46$ & 108 & 11 & $3.1(1.4,7.0)$ & $1.8(0.7,4.9)$ \\
\hline \multicolumn{5}{|l|}{ Education } \\
\hline No education & 300 & 40 & Ref. & Ref. \\
\hline Primary school & 200 & 33 & $0.8(0.5,1.3)$ & $1.1(0.6,1.9)$ \\
\hline Secondary + & 65 & 23 & $0.4(0.2,0.7)$ & $0.5(0.2,1.2)$ \\
\hline \multicolumn{5}{|l|}{ knowledge } \\
\hline Good & 318 & 76 & Ref. & Ref. \\
\hline Poor & 247 & 20 & $2.9(1.8,4.9)$ & $3.0(1.7,5.5)$ \\
\hline
\end{tabular}




\begin{tabular}{|c|c|c|c|c|}
\hline \multirow[t]{2}{*}{ Variables } & \multicolumn{2}{|l|}{ Level of Attitude } & \multirow[t]{2}{*}{$\operatorname{coR}(95 \% \mathrm{Cl})$} & \multirow[t]{2}{*}{ AOR(95\%Cl) } \\
\hline & Unfavorable attitude & Favorable attitude & & \\
\hline \multicolumn{5}{|l|}{ Occupation } \\
\hline Gov.employee & 69 & 15 & Ref. & Ref. \\
\hline Farmer & 353 & 43 & $1.8(0.9,3.4)$ & $0.5(0.2,1.4)$ \\
\hline Merchant & 59 & 6 & $2.1(0.8,5.9)$ & $1.2(0.4,3.7)$ \\
\hline House wife & 84 & 32 & $0.6(0.3,1.1)$ & $0.2(0.1,0.6)$ \\
\hline \multicolumn{5}{|l|}{ Family size } \\
\hline$\leq 3$ & 240 & 52 & Ref. & Ref. \\
\hline$\geq 4$ & 325 & 44 & $1.6(1.0,2.5)$ & $0.9(0.6,1.6)$ \\
\hline \multicolumn{5}{|l|}{ Comorbidity } \\
\hline Yes & 131 & 8 & Ref. & Ref. \\
\hline No & 372 & 88 & $0.3(0.1,0.5)$ & $0.3(0.1,0.6)$ \\
\hline Unknown & 62 & 0 & - - & -- \\
\hline
\end{tabular}

Factors associated with the level of preventive practice towards COVID-19 pandemic

The result of this study revealed that residence of study participants, occupation, and having confirmed comorbidity were factors associated with the level of preventive practice. Respondents residing in urban area had better preventive practice (AOR: $0.2,95 \% \mathrm{Cl}: 0.1,0.3$ ) than study participants living in rural area. 
Table 4

Univariable and multivariable binary logistic regression analysis on factors associated with the level preventive practice towards COVID-19 in east Gojjam Zone, 2020

\begin{tabular}{|c|c|c|c|c|}
\hline \multirow[t]{2}{*}{ Variables } & \multicolumn{2}{|c|}{ Level of practice } & \multirow[t]{2}{*}{$\operatorname{coR}(95 \% \mathrm{Cl})$} & \multirow[t]{2}{*}{$\mathrm{AOR}(95 \% \mathrm{Cl})$} \\
\hline & Poor practice & Good practice & & \\
\hline \multicolumn{5}{|l|}{ Gender } \\
\hline Male & 191 & 57 & Ref. & Ref. \\
\hline female & 332 & 81 & $1.2(0.8,1.8)$ & $1.2(0.8,1.9)$ \\
\hline \multicolumn{5}{|l|}{ Residence } \\
\hline Rural & 383 & 50 & Ref. & Ref. \\
\hline Urban & 140 & 88 & $0.2(0.1,0.3)$ & $0.2(0.1,0.3)$ \\
\hline \multicolumn{5}{|l|}{ Marital status } \\
\hline Unmarried & 45 & 7 & Ref. & Ref. \\
\hline Married & 406 & 128 & $0.5(0.2,1.1)$ & $0.4(0.2,1.0)$ \\
\hline Divorced & 47 & 3 & $2.4(0.6,10.0)$ & $2.1(0.5,9.0)$ \\
\hline Widowed & 25 & 0 & -- & --- \\
\hline \multicolumn{5}{|l|}{ Age } \\
\hline$\leq 25$ & 59 & 16 & Ref. & Ref. \\
\hline $26-35$ & 201 & 68 & $0.8(0.4,1.5)$ & $0.8(0.4,1.5)$ \\
\hline $35-45$ & 168 & 30 & $1.5(0.8,2.9)$ & $1.3(0.6,2.8)$ \\
\hline$\geq 46$ & 95 & 24 & $1.1(0.5,2.2)$ & $0.7(0.3,1.6)$ \\
\hline \multicolumn{5}{|l|}{ Education } \\
\hline No education & 271 & 69 & Ref. & Ref. \\
\hline Primary school & 196 & 37 & $1.3(0.9,2.1)$ & $1.6(1.0,2.7)$ \\
\hline Secondary + & 56 & 32 & $0.4(0.3,0.7)$ & $0.8(0.4,1.8)$ \\
\hline \multicolumn{5}{|l|}{ knowledge } \\
\hline Good & 311 & 83 & Ref. & Ref. \\
\hline Poor & 212 & 55 & $1.1(0.7,1.5)$ & $0.6(0.4,1.1)$ \\
\hline
\end{tabular}




\begin{tabular}{|lllll|}
\hline Variables & \multicolumn{2}{l}{ Level of practice } & COR(95\%Cl) & AOR $(95 \% \mathrm{Cl})$ \\
\cline { 2 - 3 } & Poor practice & Good practice & & \\
Attitude & & & & \\
Favorable & 77 & 19 & Ref. & Ref. \\
Unfavorable & 446 & 119 & $0.9(0.5,1.6)$ & $0.8(0.4,1.5)$ \\
Occupation & & & & \\
Gov.employee & 53 & 31 & Ref. & Ref. \\
Farmer & 337 & 59 & $3.3(1.9,5.6)$ & $2.9(1.3,6.2)$ \\
Merchant & 40 & 25 & $0.9(0.5,1.8)$ & $0.6(0.3,1.4)$ \\
House wife & 93 & 23 & $2.4(1.3,4.5)$ & $1.7(0.8,1.8)$ \\
Family size & & & & \\
$\leq 3$ & 225 & 67 & Ref. & Ref. \\
$\geq 4$ & 298 & 71 & $1.3(0.9,1.8)$ & $1.0(0.7,1.6)$ \\
Comorbidity & & & & \\
Yes & 112 & 27 & Ref. & Ref. \\
No & 352 & 108 & $0.8(0.5,1.3)$ & $0.8(0.5,1.4)$ \\
Unknown & 59 & 3 & $4.7(1.4,16.3)$ & $3.9(1.1,13.8)$ \\
\hline
\end{tabular}

Risk perception and challenges of COVID-19 prevention and control in east Gojjam Zone

A total of 9 individuals were participated in the study for an in-depth interview with median age of 32 years, ranging from 19 to 50 years. 
Table 5

Showed Distribution of the Socio-demographic Characteristics of respondents, East Gojjam Zone community; Northwest Ethiopia. Sep, 2020.

\begin{tabular}{|lllll|}
\hline S. No & Variable & & Frequency & $\%$ \\
\hline $\mathbf{1}$ & Sex & female & 2 & 22.2 \\
\cline { 3 - 5 } & & Male & 7 & 77.3 \\
\hline $\mathbf{2}$ & \multirow{2}{*}{ Marital Status } & married & 6 & 66.7 \\
\cline { 3 - 5 } & & single & 3 & 33.3 \\
\hline 3 & Educational Level & illiterate & 4 & 44.4 \\
\cline { 3 - 5 } & & primary education & 2 & 22.2 \\
\cline { 3 - 5 } & & Secondary and above & 3 & 33.3 \\
& \multirow{4}{*}{ Occupation } & Merchant & 3 & 33.3 \\
\cline { 3 - 5 } & & Government employee & 4 & 44.4 \\
& & Farmer & 2 & 22.2 \\
\hline & & Total & 9 & 100.0 \\
\hline
\end{tabular}

After analysis and reviewing articles, in this study both emerged (psychosocial and perceived behavior) and predefined (perception of susceptibility to a health threat, the perception of its severity, and the perception of the benefits, costs and barriers) themes were identified.

In this finding, the higher portion of the respondents had awareness on the occurrence of the virus. Some understood that it is originated from animals whereas a few of them believed the virus as a result of God punishment to humans and other say it is a man-made virus. Contrarily, some respondents still had doubt about the existence of the virus they are ignorant. The level of ignorance could create a problem as this set of individuals about spreading the disease.

Almost all respondents were highly understood the disease prevention strategies; but nearly all were not practicing all. This is because they believed /denied as the occurrence of the case in the study settings. In the study area, some claimed that if the case is why measures were not taken in market pleases; but the state tried to implement in the religion/faith based organization. This made a question for respondents to believe the occurrence of the disease. A few respondents believed that the only solution to prevent the virus is praying for our Lord/God. Most respondents do their job for the sake of living. Respondents have strong spiritual feelings and sense of right and wrong have made them to perform their duties as usual. The respondents' being trustful/abide for God and will not make anything to them and some perceived as it (COVID-19) is because of $\sin$. 


\section{Theme 1: Psychosocial Emotions}

\section{A. Negative Emotions in the Early Stage}

All study subjects experienced a significant amount of negative emotions in the first week, especially in the period when officials providing acquaint to the first time about the occurrence of the disease. As stated by a few respondents, as the first case notified in the country the concern about everything continued to rise. When normal work hours changed and proclamations declared; warries increased and the community were conserve many things necessary for survival for them as well their family. Some respondents failing to meet physical and psychological needs brought a sense of helplessness. Most of the respondents felt different levels of anxiety. All most all expressed concern about the impact of the outbreak on the health of their families. They also said that their families were worried about it too.

"Firstly, at the occurrence of the disease and at the time of the officials notifying about the disease; I was very nervous, the overall activity was very troublesome, made frustrations.... Even I was not confident to be out of home, to perform my routine activities and ... All conditions were upsetting me." (Respondent 6, male43 year's old daily laborer)

\section{B. Physical Distancing perceived as a Loss for intimacy}

Many participants felt that the physical distancing and isolation polices had had significant social and psychological impacts on individuals lives, many of the respondents explained physical distancing is in accordance with the lives of this community. Every activity performed together with others (significant others, friends, families...). Being distance physically, some experience sense of loss, in-person (social interaction) and loss of routine. These in turn led to 'losses' to emotion, motivation, and self-worth. This is central to loss of social interaction. The lack of face-to-face contact had, leaving participants upset in their feeling. This was stated by a respondent as,

" No one has performed/or live alone. The nature of our family is extended type so what? It is very embracing for someone to be said kept your distance from me. ... if someone/intimates/ said/ ordered me to be sand far ... I don't have any word to state my filling. " (Respondent 1, male24 years old trader).

Participants explained how impacts like physical distancing and not being able to socialize with friends, meant they experienced a general loss of meaning in life. Some respondents felt that direction on physical distancing had been generally unclear, and that information about the problem had conveyed 'mixed messages' and a few participants described a lack of trust, who were seen to be politicizing the case. A few participants explained that being physically distant, inability to socialize, and the loss of social support led to them feeling a loss of 'self-worth'.

"I tried to know about the situation, seen professionals to advocate and tried to message about distancing in the straight, market please and on media too. They/professionals/ advised the community to ..., the government set a strategy to be far from my intimates, but in my opinion noting is said about 
marketing. This is a paradox for me to accept the message and implement distancing. This feel me something.... Ohhh...." Respondent 7, 28 year's old lady).

\section{Theme 2: Perceived susceptibility}

Regarding respondents' individual susceptibility for the disease, a few individuals are susceptible for the disease and a few of them may claim they may have the virus unless they are tested and know their status. A participant perceived the disease is belonging to common cold family. A few respondents experience a mild flu like symptoms and they claim this situation as it happens for the virus.

"In my opinion the virus is a common cold one. Everyone may be infected with common cold. If so every one may be prone to the virus and develop the disease. As of I am too." (Respondent 1, male24 year's old trader)

\section{Theme 3: Perceived severity of the disease threat}

As all respondents stated that they have no experience for the case/the disease. Theoretical all have the information about the severity of the disease. All claim about pain especially head ache and death cause by the virus/disease. Some respondents pursue experiences stated by real individuals from a media about the severity of the disease. The current COVID-19 Socio-economic impacts are challenging the delivery of essential services to the most affected segments of the population. These consequences (social and economic) of the disease were well explained by all respondents and stated by a respondent as:

".... Of course, it is difficult and painful for an individual to see professionals who wear protective clothes and equipment as we see via media. It makes something wrong in your feeling, emotion...... this show how it needs a caution and sever is. This causes a person to be in a dilemma of being how much the case is too sever ... and the rumors in our locality." (Respondent 1, male24 year's old trader)

Theme 4: Perceived Barriers to COVID-19 Prevention

\section{Information Overload, but Lack of Trusted Sources}

Respondents' reported being assaulted with information about COVID-19, including from social media, mostly (TV), and as well radio, government announcements, and through face-to-face conversations with neighbors during kettle ceremonies. Despite that, individuals still have many uncertainties regarding the existence of the case:

" I still feel like people have so many questions, they want answers in a clear way about the mechanisms of transmission, and the exact time to be stop, the current situation how it continues....? (Respondent 1, male24 year's old trader)

As explained by some respondents, even government information was perceived to be unreliable with the understanding that it was aimed at maintaining government interests. The information and rumors 
spread in part cause fear and emotion. Media played a very big role in creating awareness and also make panic to many individuals. This led to individuals to perceived as COVID-19 was more dangerous, which create fear and anxiety within the communities. However, the information and rumors also created wrong perceptions to the situation, individuals perceived differences among the black and white race in immunity towards the virus/disease with suggestions given by a respondent that:

"... in my perception the virus cannot affect more us; we have /among the blacks and white/ a difference during our development. We/blacks are prone for many cases. We lived in most circumstances ... these may help us to resist conditions. Also our/communities in the setting/feeding habits help us too. Thanks to our herbals, I always use hot drinks by adding garlic, lemon, 姆 姆, 姆姆, ginger ..." (Respondent 1, male24 years old trader)

About the spread of COVID-19, respondents' experiences during the early days of the spread of COVID-19 due to its novel dimensions, they/some participants/ were feel helpless and frustrated, and feel sense of loss their love and made ambiguity on the help of their family if it happened on either side and they had to do many unusual activities. One of the respondents described as:

"I remember the day when our prime said something about the disease... I was become ...... something which made me uncomfortable and less effortful to do something in my way. I was tried to know many about the disease; but nothing I found.... walking here and there... aggressive even for my kids... I was not correct on that occasion." (Respondent 7, 28 years old lady).

\section{Social barriers}

Social barriers were the other challenge to individuals to practice the prevention measures for COVID-19. Individuals in the area have had strong social interaction and there is extended family structure. Lack of attention paid to COVID-19 by the community, customs and common beliefs, and community resistance against messages delivered by different means for prevention behaviors had fell manifest in today's individual's life style in the society, and failed to talks about health, rather living manner. One of the respondents reiterated this as:

"One part of this problem is rooted in the structure of the society. I mean, there are very strict norms as barriers. Customs and common beliefs have become barriers. If laws are passed and everything is based on religion, the society resists against these correcting behaviors." (Respondent 4, 36 years old man)

Battle for independence and striving for living as well as lack of interactions with individuals who have a better understanding regarding COVID-19 and officials and negligence were among other barriers for strategy implementation. A respondent restated this as:

"Individuals want to be independent. Someone never listen to their parents or colleagues. There have been talk and discuss about the situation/outbreak in their family and/or groups about the outbreak together with their family/colleagues. Young adolescents and some individuals do not communicate/ignore the discussion with their families/colleagues at all and they do whatever they like. 
They/some individuals have the information about COVID-19; but nothing they do." (Respondent 8, male

\section{0 years old)}

\section{Information and Communication Weaknesses}

Lack of asking questions and getting appropriate information about an issue among the community, incomplete and inaccurate information and rumors about COVID-19 among individuals, and irrational shame about practicing some prevention strategies were some important barriers stated by the respondents'. A Participant said that:

"I honestly do not ask any questions about these issues from my family. I really feel embarrassed. I try to find my answers for myself mostly using my phone from Facebook. I do not know the answers retrieved are right or wrong, but I usually get the information from the Internet. Until now, I have had no interest to talk to my parents and with those who have a better understanding about the situation." (Respondent 1 , male24 years old trader)

Family inadequacy on information about COVID-19 is one of the perceived barriers in the study setting for COVID-19 prevention strategy. Low parental awareness regarding COVID-19 transmission, passiveness of family concerning COVID-19 health information, belief of family toward COVID-19 prevention behavior, individual refusal (shame) to practice, and denial on the existence of the virus at the community could all slow down to practice the recommended prevention mechanisms in the study setting. A participant stated that:

“This is my opinion, "I can't believe on the use of mask.... He smiles and he observe me diagonally; ... 怄妪

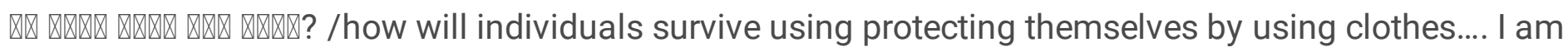
not confident enough to use it (the mask) ... because I am not believing about the purpose." (Respondent

\section{2 , male50 years old urban resident)}

\section{Individuals' Concerns About Being Judged by Others}

As few respondents stated, uncertainty of confidentiality of information, and fear of losing social interaction among individuals, and finally individuals' concerns about being judged by others were among barriers to COVID-19 prevention mechanisms' in the study community. In this regard, one of the respondents stated this as:

"In the first weeks of the occurrence of the disease; I was doing what it was said. Mostly I tried to stay to my home together with my family. I was feared and worried about many issues for my living. Later I left from my house and tried to practice what officials and professionals said to prevent myself and my family from the case. ... was wash my hands frequently, use mask in market areas as well when I work my duties. Always my friends were laughing with me about what I was done and at one day my fried said

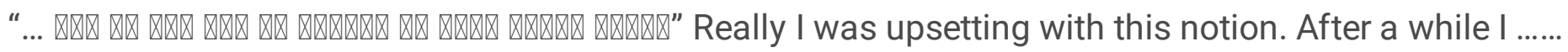
everything what it was expected." (Respondent 6 , male43 years old daily laborer). 


\section{Discussion}

A community based study to assess knowledge, attitude, practice, risk perceptions and challenges towards COVID-19 was conducted in east Gojjam Zone. The study was encompassed both male (37.5\%) and female $(62.5 \%)$ with great females response. From study participants only $(59.6 \%(95 \% \mathrm{Cl}: 55.8,63.6)$ have shown a good knowledge on COVID-19 prevention with high variation outcome with conducted at Illu Aba Bor and Buno-Bedelle Zones, Southwest Ethiopia (93.3\%) (27). Early studies which has been conducted in Bangladesh has identified similar outcome with this study. On the another hands, the level of knowledge has been assessed as good for both gender with male AOR $1.4(0.9,2.1)(28)$.

Another important finding of this study is that the attitude of respondents towards COVID-19 and its preventive measures. The results of this study showed that the overall level of attitude towards COVID-19 and its preventive measures among rural communities of East Gojjam zone in the Amhara regional state of North West Ethiopia is very low. In this study only $14.5 \%(95 \% \mathrm{Cl}: 11.6,17.1)$ of respondents had favorable attitude towards covid-19 and its preventive measures which indicates a large proportion of respondents have had unfavorable attitude. This finding is almost comparable with a study done in Uganda which has been reported as nearly $21 \%(n=29)$ of health care workers had positive attitude toward COVID-19 (29).

The finding of this study was by far lower than the previous studies done in different parts of Asia and Africa. For instance: in Asia particularly in Bangladeshi (30), China (31) and Saudi Arabia (32) about $52.4 \%, 73.81 \%$ and $86.6 \%$ of respondents reportedly had favorable attitude towards COVID-19 and its preventive measures respectively. Similarly in Africa; in study done in Egypt (33) and North-Central Nigeria (34) more than $75.9 \%$ and $79.5 \%$ of respondents reported as having favorable attitude towards covid-19 respectively.

The possible reason for the discrepancies of this result might be the difference in study population and methods of data collection in that unlike this study; most of previous studies collect data from educated and those populations having internet access through online data collection methods (29-33), which is prone to selection bias and unrepresentativeness.

The third main outcome of this study was the practice level towards COVID-19 preventive measures and factors affecting it among East Gojjam Zone, North West Ethiopia. The result indicated that, the magnitude of poor practice was very high in this study, despite the government's effort to improve the challenges. This finding is higher than studies conducted in Iran (35), face book based online study in Ethiopia by Bekele $D$ et al (36). The possible reason might be a difference in sources of information especially undefined rumors, different myths, less information-seeking behavior, lack of modern main stream media and social media exposure towards COVID-19 disease. Moreover, the current study was conducted mainly in rural residents of East Gojjam Zone, which has limited cell phone based internet, the study participants were mainly farmers in their occupation and contributes to limited access to information towards COVID 19 disease. In addition, the study participants may believe that their feeding practice and God/Allah prevent them from COVID-19 and fail to practice appropriately. 
Unlike the current study findings the Sudanese people were practiced many preventive measures such as, staying at home, frequent hand washing, using antiseptics, and wearing masks, avoiding hand shaking and visiting over crowded places $(37,38)$.

Similarly, the current finding is much higher than studies conducted in Saudi Arabia, Malaysia, Philippines, and China (39-42). This might be due to different parameters used to quantify outcome of interest. i.e. in our case we used 3/4th of the correct response to measure the good and poor practice of the preventive measures where us in Saudi Arabia, the mean score was used as measurement of practice status towards COVID 19 preventive measures. Moreover, the variation might be due to socio demographic and cultural difference across the Ethiopia, China, Philippines, Malaysia and Saudi Arabia.

The studies conducted in Arba Minch town, Southern Ethiopia, Bangladesh and review articles conducted on knowledge, attitude and practice among Ethiopian residents share similar features on the limited practice of preventive measures towards COVID-19 pandemic disease (43-45). This might be due to the inability to afford and the scarcity of the mask in the country. Generally, these poor practices in this study might be primarily attributed to the lack of strict prevention and control measures implemented by local government, such as banning public gatherings and enforcing peoples to wear a mask. It could also be the result of the patients' poor knowledge regarding the high infectivity of the COVID-19 virus. Besides, the poor practice in this study may be attributed to the less serious situation of the COVID-19 in the Ethiopia and Bangladesh, at large besides study areas.

In spite of, this result the study from Sudan indicated that $\leq 25$ aged respondents had good knowledge than other age groups with AOR $5.6(2.6,12.4)(46)$. This variation might be the proper utilization of technologies and Medias for COVID-19 prevention purpose. In this study the respondents with no formal education were the poor knowledgeable with AOR $4.7(1.8,12.1)$ which has similar outcome with $(46)$.

Regarding factors associated with the level of attitude towards COVID-19 and its preventive measures; in this study residence (AOR: 0.5 (95\% Cl: 0.3, 0.8)), Comorbidity (AOR: 0.3 (95\% Cl: 0.1, 0.6)); occupation (being house wife) (AOR: 0.2(95\% Cl: 0.1, 0.6)); and respondents knowledge towards COVID-19 (AOR: $3.0(95 \% \mathrm{Cl}: 1.7,5.5)$ were statistically and significantly associated the level of attitude towards COVID-19 and its preventive measures.

Those respondents having previous comorbidity were $70 \%$ less likely to have unfavorable attitude towards COVID-19 and its preventive measures compared with those who had not comorbidity. Likewise, those respondents who were civil servants occupationally were $80 \%$ less likely to have unfavorable attitude towards COVID-19 and its preventive measures compared to housewives while those who had poor knowledge towards COVID-19 were three times more likely to have unfavorable attitude towards COVID-19 and its preventive measures compared to their counterparts.

This result is supported with previous done in Bangladeshi (45): those who were working as government staff (civil servants) were more likely to had positive attitude towards COVID-19 compared to their counter parts. This consistent result might be explained by the fact that those working as civil servants are 
generally educated and might have access to health information required to establish beliefs and attitudes towards preventive measures of a pandemic. In addition this finding is supported by previous studies done in Ethiopia among health professionals which reveled having good knowledge $(A O R=3.17$; $95 \% \mathrm{Cl}: 1.97,5.06)$ was positively associated with the attitude of health care providers towards COVID-19 (47).

Moreover those who had good attitude had favorable attitude towards COVID-19 and its preventive measures. This finding is in line with the theory which states knowledge is the pre request to have positive attitude and good practice.

The factors associated with poor practice of preventive measures towards COVID-19 in East Gojjam community were study participants with primary Education (AOR: 1.6 (95\% Cl: 1.0, 2.7)), being farmer in occupation (AOR: 2.9 (95\% Cl: 1.3, 6.2)), urban residence (AOR: 0.2 (95\% Cl: 0.1, 0.3)), and participants who didn't know comorbidity (AOR: 3.9, $(95 \% \mathrm{Cl}: 1.1,13.8)$ ). The current study and studies in Iran mentioned lower education as factor or poor preventive measures $(35,48)$. This is due to the fact that as educational level decreases from higher to lower; it leads to less understanding of the pathogenesis and infectivity of the disease and non-compliance to preventive measures. However, with similar topic of study the additional factors were age, male gender, being single, and having health-care-related occupations were significantly associated with lower practice $(35,43,44,49,50)$.

Study participants with the educational status of primary education were more likely to have poor practice than those with educational status of "secondary and above". Similar to this finding, a study in Iran showed that higher level of education was associated with high practice score. This may be due to the fact that education is an influential determining factor of healthy behavior. As one gets more educated, there will be multiple ways of acquiring information to know about the prevention of COVID-19 and will practice accordingly. Also, when someone gets more educated he/she will have a better understanding of control measures and preventive strategies related to COVID-19, and the ability to practice recommendations to protect COVID-19 will increase

\section{Limitations}

The study has several limitations worthy of further discussion. It was measured through community selfreport and thereby exposed to the subjectivity. A further limitation is that the gold standard for estimating practice of COVID 19 prevention measures is arguably direct observation. But, due to budget scarcity, direct observation has not been conducted; therefore the accuracy of estimates level of practice was obtained through self-report compared to this gold standard is unknown and the potential for response bias must be considered.

\section{Conclusion}

In conclusion, only one third of respondents had better understanding of COVID-19 pandemic. Similarly, less-than one-fifth of individuals had favorable attitude towards COVID-19. Specifically, about one third of 
individuals believed that COVID-19 comes for sinners. This study has also showed that only one-fifth of study participants had good preventive practices. Residing in rural area, not having formal education and being below age of 25 age of were factors significantly associated with the poor level of knowledge towards COVID-19. Having poor level of knowledge, residing in rural area and having confirmed comorbidity were factors associated with unfavorable attitude towards COVID-19. Furthermore, respondents with confirmed comorbidity had good preventive practice towards COVID-19. Based on the result obtained in this study the following recommendations are forwarded: Address peoples who are living at rural area through health professionals in order to create public awareness towards COVID-19 is recommended, Leaflets prepared in local languages about COVID-19 to the community should be administered, the health education programs should be continued in uncompromising and intensified way in rural community, religious leaders should teach the believers by interacting faith and science on the means of preventing the pandemic.

\section{Abbreviations}

Not applicable.

\section{Declarations}

\section{Ethics approval and consent to participate}

The study was reviewed and approved by the Debre Markos University, Ethical Clearance Committee. All participants were informed about the aim of the study and their full right to withdraw or refuse to participate before their written informed consent was obtained. Written informed consent was obtained from each participant.

\section{Consent for publication}

Not applicable

\section{Availability of data and materials}

All the data supporting the study findings are within the manuscript.

\section{Competing interests}

The authors declared no conflict of interest

\section{Funding}

Debre Markos University funded this study.

\section{Author's contributions}


BT, MA, WG, YL, \& NM conceived and designed the study, performed analysis and interpretation of data. $\mathrm{MM}, \mathrm{MW}, \mathrm{MA}, \mathrm{YT}, \mathrm{GG}, \mathrm{AA}, \mathrm{BK}, \mathrm{GD}$ and $\mathrm{AA}$ supervised the design conception, analysis, interpretation of data and made critical comments at each step of the research. BT, MA, WG, YL, \& NM drafted the manuscript, read and approved the final manuscript. Finally all authors have read and approved the manuscript.

\section{Acknowledgments}

We would like to express our gratitude to data collectors and supervisors for their data collection and to respondents for their willingness to participate in the study. We also like to thank Debre Markos University for issuing Ethical Clearance, funding this research and Woreda officials for their cooperation.

\section{References}

1. WMHC. Wuhan Municipal Health and Health Commission's Briefing on the Current Pneumonia Epidemic Situation in Our City. 2020. http://wjw.wuhan. gov.cn/front/web/showDetail/2019123108989. Accessed 1 Feb 2020.

2. World Health Organization (WHO). Report of the WHO-China Joint Mission on coronavirus disease 2019 (COVID-19). Available from www.who.int/docs/default-source/coronaviruse/whochina- jointmission-on-covid-19-final-report.pdf (accessed 29 February 2020).

3. Chinese Center for Disease Control and Prevention. Epidemic update and risk assessment of 2019 novel coronavirus 2020. 2020. http://www.chinacdc.cn/yyrdgz/202001/P020200128523354919292.pdf (accessed Feb 18, 2020).

4. Read JM, Bridgen JR, Cummings DA, Ho A, Jewell CP. Novel coronavirus 2019-nCoV: early estimation of epidemiological parameters and epidemic predictions. medRxiv 2020; Vol. version 2. [DOI: 10.1101/2020.01.23.20018549].

5. Cetron M, Landwirth J. Public health and ethical considerations in planning for quarantine. Yale Journal of Biology and Medicine 2005;78(5):329-34.

6. Jernigan DB. Update: Public Health response to the coronavirus disease 2019 outbreak - United States. MMWR. Morbidity and Mortality Weekly Report 2020;69:216-9.

7. World Health Organization (WHO). Considerations for quarantine of individuals in the context of containment for coronavirus disease (COVID-19). Available from www.who.int/ internal-publicationsdetail/considerations-for-quarantineof- individuals-in-the-co.

8. https://www.bbc.com/news/world-asia-china-51368873.

9. FMOH. National Comprehensive COVID-19 Management Handbook.First edition, April 2020.

10. Patient education: Coronavirus disease 2019 (COVID-19) overview (The Basics).

11. Zhu N, Zhang D, Wang W, Li X, Yang B, Song J, et al. A novel coronavirus from patients with pneumonia in China, 2019. N Engl J Med. 2020. https:// doi.org/10.1056/NEJMoa2001017.

12. WHO. Coronavirus. 2020. https://www.who.int/health-topics/coronavirus. Accessed 1 Feb 2020. 
13. Adhikari SP, Meng S, Wu YJ, Mao YP, Ye RX, Wang QZ, Sun C, Sylvia S, Rozelle S, Raat H, Zhou H. Epidemiology, causes, clinical manifestation and diagnosis, prevention and control of coronavirus disease (COVID-19) during the early outbreak period: a scopin.

14. CDC. 2019 Novel coronavirus, Wuhan, China. 2020. https://www.cdc.gov/ coronavirus/2019nCoV/summary.html. Accessed 1 Feb 2020.

15. Lupia T, Scabini S, Pinna SM, Di Perri G, De Rosa FG, Corcione S. 2019-novel coronavirus outbreak: A new challenge. Journal of Global Antimicrobial Resistance. 2020 Mar 7.

16. Li Q, Guan X, Wu P, Wang X, Zhou L, Tong Y, et al. Early transmission dynamics in Wuhan, China, of novel coronavirus-infected pneumonia. N Engl J Med. 2020.

https://doi.org/10.1056/NEJMoa2001316.

17. World Health Organization. Coronavirus. Overview. . Accessed 23 Mar 2020.

18. Bai Y, Yao L, Wei T, Tian F, Jin DY, Chen L, Wang M: Presumed Asymptomatic Carrier Transmission of COVID-19. JAMA 2020.

19. Wang D, Hu B, Hu C, Zhu F, Liu X, Zhang J, Wang B, Xiang H, Cheng Z, Xiong Y et al: Clinical Characteristics of 138 Hospitalized Patients With 2019 Novel Coronavirus-Infected Pneumonia in Wuhan, China. JAMA 2020.

20. Huang C, Wang Y, Li X, Ren L, Zhao J, Hu Y, Zhang L, Fan G, Xu J, Gu X et al: Clinical features of patients infected with 2019 novel coronavirus in Wuhan, China. The Lancet 2020.

21. Chang, Lin M, Wei L, Xie L, Zhu G, Dela Cruz CS, Sharma L: Epidemiologic and Clinical Characteristics of Novel Coronavirus Infections Involving 13 Patients Outside Wuhan, China. JAMA 2020.

22. Chen N, Zhou M, Dong X, Qu J, Gong F, Han Y, Qiu Y, Wang J, Liu Y, Wei Y et al: Epidemiological and clinical characteristics of 99 cases of 2019 Page 20 of 25 Journal Pre-proof 20 novel coronavirus pneumonia in Wuhan, China: a descriptive study. Lancet 20.

23. Liu Y, Gayle A, Wilder-Smith A, J. R: The reproductive number of COVID-19 is higher compared to SARS coronavirus. J Travel Med 2020, https://doi.org/10.1093/jtm/taaa021.

24. Chan JFW, Lau SKP, To KKW, Cheng VCC, Woo PCY, Yuen K-Y: Middle East respiratory syndrome coronavirus: another zoonotic betacoronavirus causing SARS-like disease. Clinical microbiology reviews 2015, 28(2):465-522.

25. Centers for Diseases Control and Prevention: Coronavirus Disease 2019 (COVID-19). 2020.

26. East Gojjam Zone Health departemnt annual report 2011, Debre Markos.

27. Tsegaye D. Knowledge and preventive practices towards Covid- 19 and associated factors among healthcare workers in selected health facilities of Illu Aba Bor and Buno Bedelle Zones, Southwest Ethiopia. 2020;

28. Hossain MA, Jahid MIK, Hossain KMA, Walton LM, Uddin Z, Haque MO, et al. Knowledge, attitudes, and fear of COVID-19 during the Rapid Rise Period in Bangladesh. PLoS One. 2020;15(9):e0239646.

29. Olum R, Chekwech G, Wekha G, Nassozi DR and Bongomin F (2020).Coronavirus Disease2019:Knowledge, Attitude, and Practices of Health Care Workers at Makerere University Teaching 
Hospitals, Uganda. Front. Public Health 8:181. doi: 10.3389/fpubh.2020.00181.

30. Paul A, Sikdar D, Hossain MM, Amin MR, Deeba F, Mahanta J, et al. (2020) Knowledge, attitudes, and practices toward the novel coronavirus among Bangladeshis: Implications for mitigation measures. PLoS ONE 15(9): e0238492. https://doi.org/10.1371/journal.p.

31. Yaling Peng, Chenchen Pei, Yan Zheng, Juan Wang, Kui Zhang, Zhaohui Zheng and Ping Zhu:A cross-sectional survey of knowledge, attitude and practice associated with COVID-19 among undergraduate students in China: BMC Public Health (2020) 20:1292. https://d.

32. Amani Alhazmi, Maha Hamed Mohamed Ali, Ali Mohieldin, Farah Aziz, Osman Babiker Osman, Waled AM Ahmed: Knowledge, attitudes and practices among people in Saudi Arabia regarding COVID-19: A cross-sectional study; Journal of Public Health Research 2020; vol.

33. Zeinab A. Kasemy, Wael A. Bahbah, Shimaa K. Zewain, Mohammed G. Haggag, Safa H. Alkalash, Enas Zahran, Dalia E. Desouky. Knowledge, Attitude and Practice toward COVID-19 among Egyptians: Journal of Epidemiology and Global Health;2020. https://doi.org/10.2.

34. Rine Christopher Reuben, Margaret M. A. Danladi, Dauda Akwai Saleh and Patricia Ene Ejembi:Knowledge, Attitudes and Practices Towards COVID 19: An Epidemiological Survey in North Central Nigeria; Journal of Community Health;2020. https://doi.org/10.1007/.

35. Erfani A, Shahriarirad R, Ranjbar K, Mirahmadizadeh A, Moghadami M. Knowledge, attitude and practice toward the novel coronavirus (COVID-19) outbreak: A population-based survey in Iran. Bull World Health Organ, E-pub. 2020 Mar;30.

36. Bekele D, Tolossa T, Tsegaye R, Teshome W. The knowledge and practice towards COVID-19 pandemic prevention among residents of Ethiopia. An online cross-sectional study. BioRxiv. 2020 Jan 1.

37. Mousa KN, Saad MM, Abdelghafor MT. Knowledge, attitudes, and practices surrounding COVID-19 among Sudan citizens during the pandemic: an online cross-sectional study. Sudan Journal of Medical Sciences (SJMS). 2020 Jun 10:32-45.

38. Al-Hanawi MK, Angawi K, Alshareef N, Qattan AM, Helmy HZ, Abudawood Y, Alqurashi M, Kattan WM, Kadasah NA, Chirwa GC, Alsharqi O. Knowledge, Attitude and Practice Toward COVID-19 Among the Public in the Kingdom of Saudi Arabia: A Cross-Sectional Study. Fr.

39. Zhong BL, Luo W, Li HM, Zhang QQ, Liu XG, Li WT, Li Y. Knowledge, attitudes, and practices towards COVID-19 among Chinese residents during the rapid rise period of the COVID-19 outbreak: a quick online cross-sectional survey. International journal of biol.

40. Hezima A, Aljafari A, Aljafari A, Mohammad A, Adel I. Knowledge, attitudes, and practices of Sudanese residents towards COVID-19. East Mediterr Health J. 2020 Jun 1;26(6):646-51.

41. Mohamed, Amal, Eilaf Elhassan, Abdelrahim O. Mohamed, Awab Aldow Mohammed, Mohamed Alhadi Mahgoop, Mohamed Emadaldin Sharif, Maab Imadeldin Bashir, Rania Bashir Abderlahim, Wegdan Ibraheim Idriss, and Elfatih Mohamed Malik. "Knowledge, attitude and practi.

42. Lau LL, Hung N, Go DJ, Ferma J, Choi M, Dodd W, Wei X. Knowledge, attitudes and practices of COVID-19 among income-poor households in the Philippines: A cross-sectional study. Journal of 
global health. 2020 Jun;10(1).

43. Azlan AA, Hamzah MR, Sern TJ, Ayub SH, Mohamad E. Public knowledge, attitudes and practices towards COVID-19: A cross-sectional study in Malaysia. Plos one. 2020 May 21;15(5):e0233668.

44. Cvetković VM, Nikolić N, Radovanović Nenadić U, Öcal A, K Noji E, Zečević M. Preparedness and Preventive Behaviors for a Pandemic Disaster Caused by COVID-19 in Serbia. International Journal of Environmental Research and Public Health. 2020 Jan;17(11):412.

45. Paul A, Sikdar D, Hossain MM, Amin MR, Deeba F, Mahanta J, Jabed MA, Islam MM, Noon SJ, Nath TK. Knowledge, attitudes, and practices toward the novel coronavirus among Bangladeshis: Implications for mitigation measures. PloS one. 2020 Sep 2;15(9):e0238492.

46. Hezima A, Aljafari A, Aljafari A, Mohammad A, Adel I. Knowledge, attitudes, and practices of sudanese residents towards covid-19. East Mediterr Heal J. 2020;26(6):646-51.

47. Kassie BA, Adane A, Tilahun YT, Kassahun EA, Ayele AS, Belew AK (2020) Knowledge and attitude towards COVID-19 and associated factors among health care providers in Northwest Ethiopia. PLoS ONE 15(8): e0238415. https://doi.org/10.1371/journal.pone.0238415.

48. Nigussie TF, Azmach NN. KNOWLEDGE, ATTITUDE AND PRACTICE TOWARDS COVID-19 AMONG ARBA MINCH TOWN, SOUTHERN ETHIOPIA. GSJ. 2020 Jun;8(6).

49. Devkota HR, Sijali TR, Bogati R, Clarke A, Adhikary P, Karkee R. How does public knowledge, attitudes, and behaviors correlate in relation to COVID-19? A community-based cross-sectional study in Nepal. medRxiv. 2020 Jan 1.

50. Teferi SC. A Review on Knowledge, Attitude, and Practice during the COVID-19 Pandemic in Ethiopia. Journal of Biomedical Research \& Environmental Sciences. 2020 Aug 29;6(8):040-4.

\section{Supplementary Files}

This is a list of supplementary files associated with this preprint. Click to download.

- STROBEchecklistcrosssectional.doc 